\title{
Effects of maturity at ensiling of bermudagrass and fibrolytic enzyme application on the performance of early-lactation dairy cows
}

\author{
J. L. P. Daniel, ${ }^{*} \dagger$ O. C. M. Queiroz, ${ }^{*}$ K. G. Arriola, ${ }^{\star}$ C. R. Staples, ${ }^{*}$ J. J. Romero, ${ }^{\star} \ddagger ~ J . ~ H . ~ S h i n,{ }^{*}$ \\ J. R. Paschoaloto, ${ }^{*}$ L. G. Nussio, $§$ and A. T. Adesogan*1 \\ *Department of Animal Sciences, Institute of Food and Agricultural Sciences, University of Florida, Gainesville 32611 \\ †Department of Animal Science, State University of Maringá, Maringá, Brazil, 87020900 \\ $\ddagger$ Animal and Veterinary Sciences Program, School of Food and Agriculture, University of Maine, Orono 04469-5763 \\ §Department of Animal Science, University of São Paulo, Luiz de Queiroz College of Agriculture, Piracicaba, Brazil, 13418900
}

\begin{abstract}
The objective of this study was to examine effects of adding fibrolytic enzymes to diets containing bermudagrass ensiled after 4 or $7 \mathrm{wk}$ of regrowth on the diet digestibility, ruminal fermentation and performance of lactating cows, and the interaction of the treatments. In experiment 1, 64 Holstein cows ( $22 \pm 4 \mathrm{~d}$ in milk) were assigned to an experiment with a $2 \times 2$ factorial treatment arrangement and a 56-d duration. Treatments were diets containing 4 or 7 wk regrowth bermudagrass silage without or with an exogenous fibrolytic enzyme cocktail. The cellulase-xylanase enzyme was applied at $2.33 \mathrm{~g} / \mathrm{kg}$ of total mixed ration dry matter (DM) during mixing immediately before feeding. Experiment 2 was aimed at examining treatment effects on the ruminal fermentation profile. Four ruminally cannulated cows were assigned to the 4 treatments using a $4 \times 4$ Latin square design with 14-d periods. No enzyme by maturity interaction was detected for any measurement. Regardless of forage maturity, applying the fibrolytic enzyme did not affect DM intake, milk yield, apparent digestibility, feed efficiency, energy balance, and ruminal fermentation though it tended to increase milk lactose concentration (4.88 vs. $4.81 \%$ ). Feeding the 4 -wk diet instead of the 7 -wk diet increased DM intake (22.4 vs. $21.3 \mathrm{~kg} / \mathrm{d}$ ), digestibility of DM, neutral detergent fiber, and acid detergent fiber, and tended to increase 3.5\%fat corrected milk yield $(47.2$ vs. $44.3 \mathrm{~kg} / \mathrm{d})$ and milk fat yield (1.88 vs. $1.73 \mathrm{~kg} / \mathrm{d}$ ). Therefore, daily intake of net energy and secretion of milk energy were greater for the 4 -wk diet. In addition, the 4-wk diet increased the ruminal concentrations of acetate, propionate, valerate, lactate, and total volatile fatty acids, and decreased ruminal $\mathrm{pH}$, without affecting the acetate:propionate ratio. Feeding fibrolytic enzymes did not improve the
\end{abstract}

Received March 29, 2016.

Accepted July 26, 2016.

${ }^{1}$ Corresponding author: adesogan@ufl.edu performance of early-lactation dairy cows, but harvesting the forage earlier tended to improve milk production.

Key words: bermudagrass, cellulase, fibrolytic enzyme, xylanase

\section{INTRODUCTION}

Bermudagrass silage is an important source of digestible fiber in dairy cow rations in the southeast United States and some tropical countries. Although Tifton 85 bermudagrass is more digestible than other warm season grasses, its digestibility is lower than those of corn or alfalfa silage or most nonforage fiber sources used in dairy nutrition in the United States. Therefore, strategies that improve the digestion and utilization of bermudagrass silage could potentially increase the performance of dairy cows in the southeast United States and tropical/subtropical climates.

Although the literature on the subject is equivocal, several experiments have shown the potential of exogenous fibrolytic enzymes to improve nutrient utilization in ruminants (Beauchemin et al., 2003; Adesogan et al., 2014), including lactating dairy cows (Lewis et al., 1999; Kung et al., 2000; Yang et al., 2000; Arriola et al., 2011; Romero et al., 2016). Such fibrolytic enzymes often increase DMI or fiber digestibility; therefore, they are most likely to increase the performance of dairy cows in negative energy balance in early lactation (Schingoethe et al., 1999; Knowlton et al., 2002). Recently, we reported that addition of 2 fibrolytic enzyme cocktails to a diet containing $10 \%$ of bermudagrass silage tended to increase FCM and milk fat yield in cows in early lactation (Romero et al., 2016).

An important strategy to increase the digestibility of bermudagrass is harvesting the forage when it is not mature. Harvesting earlier regrowths of bermudagrass (e.g., 3 to $4 \mathrm{wk}$ ) instead of late regrowths (e.g., 7 to 8 wk) reduces forage production per harvest (e.g., 2.8 vs. $5.8 \mathrm{t}$ of $\mathrm{DM} /$ ha per harvest; Mandebvu et al., 1999), 
but usually increases digestibility and $\mathrm{CP}$ concentration and could potentially improve milk yield in lactating dairy cows (Chambliss et al., 1999; Mandebvu et al., 1999). To our knowledge, no study has examined if the potential benefits of applying exogenous fibrolytic enzymes to diets and harvesting the dietary bermudagrass early would result in synergistic increases in the digestibility of the diet and the performance of lactating dairy cows.

The objective was to examine the effects of adding a fibrolytic enzyme cocktail to diets containing 4 or 7 wk regrowth bermudagrass silage on the performance of dairy cows in early lactation. We hypothesized that application of the enzyme and feeding the less mature forage would synergistically increase the DMI, DM digestibility, and performance of lactating dairy cows. In addition, we hypothesized that the greatest increases in DMI, DM digestibility, and milk production would occur when the enzyme is applied to the less mature bermudagrass silage.

\section{MATERIALS AND METHODS}

\section{Experiment 1: Treatments, Cows, and Sampling}

Tifton 85-bermudagrass was grown at the Dairy Unit, University of Florida and fertilized with $415 \mathrm{~kg} /$ ha of $\mathrm{N}$ and $162 \mathrm{~kg} / \mathrm{ha}$ of $\mathrm{K}_{2} \mathrm{O}$ per year. The field was staged by mowing to a 5 - $\mathrm{cm}$ stubble $7 \mathrm{wk}$ before the anticipated harvest date. Three weeks later, the forage on half of the field assigned to the 4-wk regrowth treatment was mowed, harvested and fed to nonexperimental cows. Seven weeks after staging, the 4- and 7-wk regrowth forage in each half of the field was mowed at a DM concentration of approximately $25 \%$ on the same morning, wilted for about $2 \mathrm{~h}$ to a DM concentration of approximately $40 \%$, chopped (5-cm theoretical length of cut), and ensiled without additive or inoculant treatment in 3-m-wide farm-scale silos. After $64 \mathrm{~d}$ of ensiling, the bermudagrass silages (Table 1) were fed with corn silage and concentrates. The TMR were formulated to be isonitrogenous and to have similar ADF and NDF concentrations (Table 2).

Care of animals used in this study followed protocols approved by the University of Florida Institute of Agricultural Science Animal Research Committee. Sixty-four lactating Holstein cows (24 multiparous and 40 primiparous) were housed in a freestall barn when they were 10 DIM and trained to receive a common TMR in feedbunks with Calan gates (American Calan Inc., Northwood, NH) for $11 \mathrm{~d}$. During the training period, the TMR contained $11.25 \%$ of 4 -wk bermudagrass silage, $11.25 \%$ of 7 -wk bermudagrass silage, $22.5 \%$ of corn silage, and $50 \%$ of concentrates (DM basis). From
Table 1. Chemical composition (mean $\pm \mathrm{SD}$ ) of bermudagrass silages harvested after 4 or 7 wk of regrowth (\% DM, otherwise stated)

\begin{tabular}{lcc}
\hline Item & $4 \mathrm{wk}$ & $7 \mathrm{wk}$ \\
\hline $\mathrm{DM}, \%$ as fed & $46.38 \pm 4.97$ & $49.75 \pm 2.48$ \\
$\mathrm{CP}$ & $18.35 \pm 0.44$ & $12.48 \pm 0.57$ \\
$\mathrm{NDF}$ & $70.38 \pm 0.39$ & $74.90 \pm 0.31$ \\
$\mathrm{ADF}$ & $40.65 \pm 0.70$ & $44.32 \pm 0.68$ \\
Hemicellulose & $29.73 \pm 0.89$ & $30.58 \pm 0.87$ \\
Ether extract & $2.35 \pm 0.39$ & $2.41 \pm 0.32$ \\
Ash & $6.92 \pm 0.28$ & $6.12 \pm 0.30$ \\
pH & $4.73 \pm 0.15$ & $4.88 \pm 0.20$ \\
Lactic acid & $1.98 \pm 0.54$ & $1.46 \pm 0.28$ \\
Acetic acid & $2.02 \pm 0.70$ & $1.10 \pm 0.34$ \\
Propionic acid & $0.14 \pm 0.12$ & $0.19 \pm 0.10$ \\
Isobutyric acid $+2,3$-butanediol $^{2}$ & $2.05 \pm 0.47$ & $1.39 \pm 0.44$ \\
Butyric acid & $0.007 \pm 0.012$ & $0.006 \pm 0.011$ \\
Isovaleric acid & $0.60 \pm 0.17$ & $0.31 \pm 0.06$ \\
Valeric acid $^{1}$ & $0.010 \pm 0.001$ & $0.009 \pm 0.001$ \\
\hline
\end{tabular}

${ }^{1}$ Hemicellulose $=$ NDF - ADF.

${ }^{2}$ Isobutyric acid and 2,3-butanediol coeluted on the chromatogram.

18 to 21 DIM, DMI and milk yield and composition were measured and used as covariates in the statistical analysis.

Cows were stratified based on parity and milk yield during the previous lactation (for multiparous cows)

Table 2. Ingredients and chemical composition of the experimental diets (\% of DM)

\begin{tabular}{lcc}
\hline Item & $4 \mathrm{wk}$ & $7 \mathrm{wk}$ \\
\hline Ingredient & & \\
Bermudagrass silage 4 wk & 22.50 & - \\
Bermudagrass silage $7 \mathrm{wk}$ & - & 22.50 \\
Corn silage & 22.50 & 22.50 \\
Dry ground corn & 25.00 & 25.00 \\
Citrus pulp & 9.14 & 7.08 \\
Peanut meal & 4.17 & 4.17 \\
Soybean meal & 5.08 & 8.12 \\
Soyplus & 3.13 & 3.13 \\
Whole cottonseed & 5.15 & 4.17 \\
Mineral-vitamin mix & 3.33 & 3.33 \\
Nutrient & & \\
DM & $55.94 \pm 1.81$ & $57.01 \pm 1.46$ \\
CP & $16.90 \pm 0.09$ & $16.82 \pm 0.12$ \\
RDP & $10.76 \pm 0.09$ & $10.61 \pm 0.09$ \\
NDF & $34.32 \pm 0.18$ & $35.09 \pm 0.49$ \\
Forage NDF & $25.04 \pm 0.18$ & $26.62 \pm 0.49$ \\
ADF & $19.08 \pm 0.14$ & $19.68 \pm 0.13$ \\
Hemicellulose & & \\
Ether extract & $15.24 \pm 0.28$ & $15.41 \pm 0.65$ \\
Ash & $4.37 \pm 0.06$ & $3.80 \pm 0.05$ \\
NFC & $6.75 \pm 0.08$ & $6.64 \pm 0.09$ \\
\hline
\end{tabular}

${ }^{1}$ Composition (DM basis): $6.35 \% \mathrm{Ca}, 1.25 \% \mathrm{P}, 3.99 \% \mathrm{Mg}, 0.07 \% \mathrm{~K}$, $0.84 \% \mathrm{~S}, 12.54 \% \mathrm{Na}, 3.08 \% \mathrm{Cl}, 945 \mathrm{mg} / \mathrm{kg}$ of $\mathrm{Zn}, 854 \mathrm{mg} / \mathrm{kg}$ of $\mathrm{Mn}$, $1,660 \mathrm{mg} / \mathrm{kg}$ of Fe, $251 \mathrm{mg} / \mathrm{kg}$ of Cu, $19 \mathrm{mg} / \mathrm{kg}$ of I, $10 \mathrm{mg} / \mathrm{kg}$ of Se, $25 \mathrm{mg} / \mathrm{kg}$ of Co, 23,591 IU $/ \mathrm{kg}$ of vitamin A, 8,493 IU $/ \mathrm{kg}$ of vitamin $\mathrm{D}_{3}, 236 \mathrm{IU} / \mathrm{kg}$ of vitamin $\mathrm{E}$, and $480 \mathrm{mg} / \mathrm{kg}$ of monensin.

${ }^{2}$ Rumen-degradable protein calculated using the NRC (2001).

${ }^{3}$ Hemicellulose $=$ NDF - ADF.

${ }^{4} \mathrm{NFC}=100-\mathrm{CP}-\mathrm{NDF}-$ ether extract - ash. 
at 22 DIM and assigned to 1 of 4 treatments for the duration of the 56-d study. The dietary treatments were arranged in a 2 (bermudagrass maturity) $\times 2$ (enzyme treatment) factorial arrangement and included the following: (1) 4-wk bermudagrass silage without enzyme, (2) 4-wk bermudagrass silage with enzyme, (3) 7-wk bermudagrass silage without enzyme, and (4) 7-wk bermudagrass silage with enzyme. The enzyme was sprayed onto the TMR and mixed for $5 \mathrm{~min}$ in a selfpropelled mixer (Data Ranger, American Calan Inc.) immediately before feeding at 0600 and $1400 \mathrm{~h}$. The liquid enzyme cocktail was a mixture of Cellulase Plus and Xylanase Plus (Dyadic Inc., Jupiter, FL) applied at 1.93 and $0.40 \mathrm{~g} / \mathrm{kg}$ of TMR DM, respectively. The enzyme mixture was prepared once a week and stored in a refrigerator at $4^{\circ} \mathrm{C}$.

Weights of the TMR offered and orts were recorded daily for each cow and the amount of offered TMR was adjusted daily to provide $110 \%$ of the DMI recorded on the previous day. Duplicate samples of bermudagrass silages, corn silage, and concentrate ingredients were collected weekly and samples of each ingredient were composited monthly and subsequently chemically analyzed, and the data were used to calculate the chemical composition of the TMR. Orts were also sampled weekly and composited monthly for analysis.

Cows were milked at 0600 and $1800 \mathrm{~h}$ daily and milk yield was recorded. The am and pm milk samples were collected on 2 consecutive days once weekly and analyzed by Southeast Dairy laboratories (Belleview, FL) for fat, protein, and lactose using a Bentley 2000 near infrared reflectance spectrophotometer (Bentley Instruments Inc., Chaska, MN). Milk energy content (Mcal $/ \mathrm{kg}$ ) was calculated as milk $\mathrm{NE}_{\mathrm{L}}=0.0929 \times \%$ fat $+0.0547 \times \%$ protein $+0.0395 \times \%$ lactose $(\mathrm{NRC}$, $2001)$. Daily excretion of milk energy $\left(\mathrm{NE}_{\mathrm{L}}, \mathrm{Mcal} / \mathrm{d}\right)$ was computed as milk $\mathrm{NE}_{\mathrm{L}} \times$ milk yield.

The BCS (1 to 5; Wildman et al., 1982) was recorded by 2 trained assessors once a week and BW was measured on 2 consecutive days after the morning milking at the beginning and end of the trial. The average BW was used to calculate the energy requirement for maintenance $\left[\mathrm{NE}_{\mathrm{M}}(\mathrm{Mcal} / \mathrm{d})=0.08 \times \mathrm{BW}^{0.75} ; \mathrm{NRC}\right.$, 2001].

To determine total-tract digestibility, cows were orally dosed with gelatin capsules containing $10 \mathrm{~g}$ of chromic oxide, twice a day from 62 to 72 DIM (d 40 to 50 of the trial), and fecal samples were collected at both times from d 45 to 50 of the trial for chromium analysis. Apparent digestibility of DM, NDF, and ADF, and diet $\mathrm{NE}_{\mathrm{L}}$ (Mcal/kg DM; NRC, 2001) were calculated. Energy balance was estimated as [(DMI $\left.\times \operatorname{diet} \mathrm{NE}_{\mathrm{L}}\right)-$ $\left.\mathrm{NE}_{\mathrm{M}}-\mathrm{NE}_{\mathrm{L}}\right]$.

\section{Experiment 2: Ruminal Fermentation}

In experiment 2, which was conducted simultaneously, 4 lactating ruminally cannulated multiparous cows were used to examine effects of the experiment 1 treatments on ruminal fermentation measures. Experiment 2 had a $4 \times 4$ Latin square design, with 14 -d periods. Cows were housed in the same barn as those in experiment 1 and fed through similar Calan gates. On d 14 of each period, ruminal fluid samples were collected from the ventral sac using a manually operated suction device immediately before the morning feeding $(0 \mathrm{~h})$ and $2,4,6,8$, and $10 \mathrm{~h}$ afterward. The samples were filtered through 2 layers of cheese cloth after which ruminal fluid $\mathrm{pH}$ was measured using an electrode (Corning Model 12, Corning Scientific Instruments, Medfield, MA). Subsequently, an aliquot (10-mL) was acidified with sulfuric acid (50\%) and frozen for lactic acid and VFA analyses.

\section{Laboratory Analysis}

Enzyme Activity. Xylanase (EC 3.2.1.8) activity was measured using oat spelt xylan as substrate (Bailey et al., 1992), whereas endoglucanase (EC 3.2.1.4) and exoglucanase (EC 3.2.1.91) activities were measured using carboxymethylcellulose or microcrystalline cellulose (Avicel) as substrate, respectively (Wood and Bhat, 1988). The assay was performed at $39^{\circ} \mathrm{C}$ and $\mathrm{pH}$ 6.0 to mimic ruminal conditions. One unit of activity of the respective enzyme was defined as the micromoles of xylose or glucose released per minute per milligram. Protein concentration $(93.264 \mathrm{mg} / \mathrm{mL})$ was measured using the Bio-Rad Protein Assay with BSA as the standard (Bio-Rad Laboratories, Hercules, CA).

Chemical Analysis. Dry matter content was measured by drying silage samples at $60^{\circ} \mathrm{C}$ for $48 \mathrm{~h}$ in a forced-air oven. Dried samples were ground to pass the 1-mm screen of a Wiley mill (A. H. Thomas, Philadelphia, PA) and analyzed for ash in a muffle furnace at $512^{\circ} \mathrm{C}$ for $8 \mathrm{~h}$. Concentrations of NDF and ADF were measured in an ANKOM 200 Fiber Analyzer (Ankom Technologies, Macedon, NY) using methods of Van Soest et al. (1991) for NDF and AOAC (1990) for ADF. Heat-stable $\alpha$-amylase was used in the NDF assay and the results are presented exclusive of residual ash. Nitrogen was determined by rapid combustion using a Macro elemental $\mathrm{N}$ analyzer (Vario MAX CN, model ID 25.00-5003; Elementar, Hanau, Germany) and CP was calculated as $\mathrm{N} \times 6.25$. Ether extract and ash were determined according to AOAC (1990). Chromium concentrations in the feces were determined according to Schneider and Flatt (1975). 
After thawing, ruminal fluid was centrifuged at 2,000 $\times g$ for $15 \mathrm{~min}$ and the supernatant was filtered with a $0.22-\mu \mathrm{m}$ syringe filter and used to quantify lactic acid and VFA by HPLC (Merck Hitachi, Elite Lachrom HTA, Tokyo, Japan). A UV detector (Merck Hitachi L-2400) set at $210 \mathrm{~nm}$ and a Bio-Rad Aminex HPX87H column (Bio-Rad Laboratories, Hercules, CA) with $0.015 M$ sulfuric acid mobile phase and a flow rate of $0.7 \mathrm{~mL} / \mathrm{min}$ at $45^{\circ} \mathrm{C}$ were used (Arriola et al., 2011).

\section{Statistical Analysis}

The data were evaluated for normality of residuals and homogeneity of variance. Afterward, data were analyzed using the MIXED procedure of SAS (SAS Institute Inc., Cary, NC). Variables recorded weekly were analyzed as repeated measures using the following model:

$$
\begin{gathered}
\mathrm{y}_{\mathrm{ijklm}}=\mu+\operatorname{Cov}+\mathrm{P}_{\mathrm{i}}+\mathrm{A}(\mathrm{M} \times \mathrm{E})_{\mathrm{j}(\mathrm{kl})}+\mathrm{M}_{\mathrm{k}}+\mathrm{E}_{\mathrm{l}} \\
+\mathrm{ME}_{\mathrm{kl}}+\mathrm{W}_{\mathrm{m}}+\mathrm{MW}_{\mathrm{km}}+\mathrm{EW}_{\mathrm{lm}}+\mathrm{MEW}_{\mathrm{klm}}+\varepsilon_{\mathrm{ijk} \mathrm{m}},
\end{gathered}
$$

where $\mu=$ overall mean; Cov $=$ covariate (measurement of the same variable made during the last $4 \mathrm{~d}$ before the treatment period); $\mathrm{P}_{\mathrm{i}}=$ fixed effect of parity $(\mathrm{i}=$ primiparous or multiparous $) ; \mathrm{A}(\mathrm{M} \times \mathrm{E})_{\mathrm{j}(\mathrm{kl})}=$ random effect of cow within maturity $\times$ enzyme interaction $(j$ $=1$ to 64$) ; \mathrm{M}_{\mathrm{k}}=$ fixed effect of bermudagrass maturity $\left(\mathrm{k}=4\right.$ or $7 \mathrm{wk}$ of regrowth); $\mathrm{E}_{1}=$ fixed effect of enzyme $\left(\mathrm{l}=\right.$ control or enzyme); $\mathrm{ME}_{\mathrm{kl}}=$ interaction of maturity and enzyme; $\mathrm{W}_{\mathrm{m}}=$ fixed effect of week $(\mathrm{m}=1$ to 8 ; repeated measure); $\mathrm{MW}_{\mathrm{km}}=$ interaction of maturity and week; $\mathrm{EW}_{\mathrm{lm}}=$ interaction of enzyme and week; $\mathrm{MEW}_{\mathrm{klm}}=$ interaction of maturity, enzyme, and week; and $\varepsilon_{\mathrm{ijklm}}=$ residual error. Auto-regressive order 1 was used as the covariance structure and cow (maturity $\times$ enzyme) was the subject. Data from measurements taken once during the trial (digestibility and energy partitioning variables) were analyzed with a model including the random effect of cow within maturity $\times$ enzyme and fixed effects of maturity, enzyme, and maturity $\times$ enzyme.

Ruminal parameters were analyzed as repeated measures with a model including random effects of cow and period, and fixed effects of maturity, enzyme, time, and their interactions. The effect of cow (maturity $x$ enzyme) was the subject, whereas auto-regressive order 1 was specified as the covariance structure. Significant differences were declared at $P \leq 0.05$ and tendencies to significance at $0.05>P \leq 0.10$. Two cows were excluded from the final performance data set before statistical analysis due to inconsistent feed intake.

\section{RESULTS AND DISCUSSION}

The xylanase, endoglucanase, and exoglucanase activities of the exogenous enzyme were $12,138,3,153$, and $3 \mu \mathrm{mol}$ of xylose or glucose released per min per $\mathrm{mg}$. These activities were of similar magnitudes to those previously reported for the same product (Arriola et al., 2011; Lynch et al., 2013; Romero et al., 2016).

Both 4- and 7-wk bermudagrass silages were well preserved based on their $\mathrm{pH}$, fermentation end products, smell, and appearance. The concentrations of isobutyric acid and 2,3-butanediol are shown together because they coeluted on the chromatogram (Table 1). The sum of the concentrations of these compounds was greater than the range in isobutyric acid concentration of 202 samples of bermudagrass silage (0.0 to $0.29 \%$ of DM) analyzed by the Dairy One Forage Laboratory from 2000 to 2016 (Dairy One, 2016), suggesting that the high value resulted from a high 2,3-butanediol concentration. Though the sum of the concentrations of both compounds was relative high $(>1 \%$ of $\mathrm{DM})$, it is unlikely this reflects a clostridial fermentation because the forages were wilted before ensiling and the silages had very low butyric acid concentrations and no off odors.

The 4-wk bermudagrass silage had more $\mathrm{CP}$ and less NDF and ADF than the 7-wk silage. Nevertheless, diets were formulated to have similar concentrations of $\mathrm{CP}, \mathrm{NDF}, \mathrm{ADF}$, hemicellulose, and NFC to ensure the effects of the enzyme and the maturity-related recalcitrance of the bermudagrass fiber could be detected (Table 2).

No enzyme by maturity interaction was detected for any of the animal measurements. Dry matter intake, milk yield, and milk components were not affected by enzyme application except for lactose concentration, which tended $(P=0.07)$ to be increased by enzyme supplementation (Table 3). Feeding the 4 -wk diet instead of the 7 -wk diet increased DMI (22.4 vs. 21.3 $\mathrm{kg} / \mathrm{d} ; P=0.05)$.

The greater DMI and $\mathrm{NE}_{\mathrm{L}}$ concentrations (1.83 vs. $1.74 \mathrm{Mcal} / \mathrm{kg}$ of DM; $P<0.01$ ) of the 4 -wk versus 7 -wk diet resulted in a $10 \%$ increase in intake of $\mathrm{NE}_{\mathrm{L}}(41.2$ vs. $37.4 \mathrm{Mcal} / \mathrm{d} ; P<0.01$; Table 4 ). This additional energy supply was partitioned to milk secretion partly because the cows were in early lactation (Knowlton et al., 2002). The higher $\mathrm{NE}_{\mathrm{L}}$ intake of cows on the 4 -wk diet probably contributed to the trends for higher yields of FCM (47.2 vs. $44.3 \mathrm{~kg} / \mathrm{d} ; P=0.08)$ and milk fat ( 1.88 vs. $1.73 \mathrm{~kg} / \mathrm{d} ; P=0.07)$ in cows fed the 4 -wk diet instead of the 7 -wk diet. This was achieved without altering the energy balance of the cows. The increase in DMI per unit of increased NDF digestibility in the 
Table 3. Performance of lactating dairy cows fed diets based on 4 or 7 wk regrowth bermudagrass with or without fibrolytic enzymes ${ }^{1}$

\begin{tabular}{|c|c|c|c|c|c|c|c|c|}
\hline \multirow[b]{2}{*}{ Item } & \multicolumn{2}{|c|}{$4 \mathrm{wk}$} & \multicolumn{2}{|c|}{$7 \mathrm{wk}$} & \multirow[b]{2}{*}{ SEM } & \multicolumn{3}{|c|}{$P$-value ${ }^{2}$} \\
\hline & Control & Enzyme & Control & Enzyme & & M & $\mathrm{E}$ & $\mathrm{M} \times \mathrm{E}$ \\
\hline DMI, $\mathrm{kg} / \mathrm{d}$ & 23.2 & 21.7 & 21.2 & 21.4 & 0.56 & 0.05 & 0.24 & 0.14 \\
\hline Milk, $\mathrm{kg} / \mathrm{d}$ & 39.3 & 38.1 & 37.3 & 38.3 & 1.05 & 0.42 & 0.92 & 0.29 \\
\hline $3.5 \% \mathrm{FCM}, \mathrm{kg} / \mathrm{d}$ & 49.3 & 45.1 & 44.0 & 44.7 & 1.63 & 0.08 & 0.28 & 0.14 \\
\hline $3.5 \% \mathrm{FCM} / \mathrm{DMI}$ & 2.14 & 2.15 & 2.17 & 2.05 & 0.08 & 0.69 & 0.50 & 0.43 \\
\hline Milk fat, $\%$ & 4.58 & 4.46 & 4.44 & 4.33 & 0.12 & 0.28 & 0.35 & 0.97 \\
\hline Milk fat, $\mathrm{kg} / \mathrm{d}$ & 1.93 & 1.82 & 1.75 & 1.70 & 0.08 & 0.07 & 0.31 & 0.71 \\
\hline Milk protein, \% & 2.71 & 2.69 & 2.66 & 2.74 & 0.04 & 0.97 & 0.43 & 0.20 \\
\hline Milk protein, $\mathrm{kg} / \mathrm{d}$ & 1.07 & 1.05 & 1.01 & 1.05 & 0.03 & 0.31 & 0.83 & 0.29 \\
\hline Milk lactose, $\%$ & 4.81 & 4.86 & 4.80 & 4.89 & 0.04 & 0.80 & 0.07 & 0.47 \\
\hline Milk lactose, $\mathrm{kg} / \mathrm{d}$ & 1.94 & 1.89 & 1.82 & 1.90 & 0.06 & 0.38 & 0.82 & 0.27 \\
\hline Milk $\mathrm{NE}_{\mathrm{L}}, \mathrm{Mcal} / \mathrm{kg}$ & 0.764 & 0.757 & 0.750 & 0.746 & 0.013 & 0.36 & 0.65 & 0.91 \\
\hline
\end{tabular}

${ }^{1}$ Enzyme mixture contained 1.93 and $0.40 \mathrm{~g} / \mathrm{kg}$ of TMR DM of Cellulase Plus and Xylanase Plus (Dyadic Inc., Jupiter, FL), respectively.

${ }^{2} \mathrm{M}=$ effect of maturity; $\mathrm{E}=$ effect of enzyme; $\mathrm{M} \times \mathrm{E}=$ interaction between maturity and enzyme.

4 -wk versus 7 -wk diet (mean of $0.19 \mathrm{~kg}$ ) was similar to the value $(0.17 \mathrm{~kg})$ reported by Oba and Allen (1999). Furthermore, a 1 unit increase in dietary DM digestibility (\%) was associated with 0.31 more $\mathrm{kg}$ of milk (milk yield increase per unit of DM digestibility increase), which matches the improvement in milk yield reported by Huhtanen (1994) when they compiled results from 8 experiments in their examination of effects of improving forage digestion on milk production.

Enzyme treatment had no effect on digestibility measures but feeding the 4 -wk diet instead of the 7 -wk diet increased digestibility of DM ( 74.5 vs. $71.5 \% ; P<$ $0.01)$, mainly because it increased $(P<0.01) \mathrm{NDF}$ and ADF digestibility (Table 5). The higher digestibility of the 4-wk diet also partly contributed to the greater $\mathrm{DMI}$ and hence greater $\mathrm{NE}_{\mathrm{L}}$ intake of the 4 -wk versus 7-wk diet.

Harvesting bermudagrass at early-growth stages is a well-known strategy to improve its nutritive value
(Utley et al., 1971; Holt and Conrad, 1986; Chambliss et al., 1999). The greater digestibility of less versus more mature $\mathrm{C}_{4}$ grasses is not exclusively caused by differences in chemical composition such as lower lignin content (Mandebvu et al., 1998), but also by differences in plant structure. This includes a greater proportion of green leaves, thinner cell walls, and less of the recalcitrant sclerenchyma and vascular tissues in less mature plants compared with mature plants (Akin et al., 1977; Wilson, 1993). The greater accessibility of cell walls to ruminal microbes and lower resistance to particle breakdown (Jung and Allen, 1995) in less mature plants likely allows higher turnover of rumen digesta and prevents or reduces rumen fill (Kammes and Allen, 2012), resulting in greater intake of digestible DM, as observed in the current trial for the 4-wk regrowth treatment.

Higher concentrations of ruminal VFA were detected in cows fed the 4 -wk versus the 7 -wk diet. This reflects the greater DMI, digestibility of DM, NDF, and ADF,

Table 4. Body weight and condition score measures and energy partitioning in lactating dairy cows fed diets based on 4 or 7 wk regrowth bermudagrass with or without fibrolytic enzyme ${ }^{1}$

\begin{tabular}{|c|c|c|c|c|c|c|c|c|}
\hline Item & \multicolumn{2}{|c|}{$4 \mathrm{wk}$} & \multicolumn{2}{|c|}{$7 \mathrm{wk}$} & SEM & \multicolumn{3}{|c|}{$P$-value ${ }^{2}$} \\
\hline Initial BW, $\mathrm{kg}$ & 580 & 547 & 560 & 562 & 10.6 & 0.83 & 0.14 & 0.09 \\
\hline BW change, $\mathrm{kg} / \mathrm{d}$ & 0.193 & 0.263 & 0.129 & 0.276 & 0.090 & 0.78 & 0.22 & 0.65 \\
\hline Initial BCS & 2.75 & 2.65 & 2.80 & 2.84 & 0.09 & 0.15 & 0.71 & 0.41 \\
\hline Final BCS & 2.73 & 2.64 & 2.70 & 2.75 & 0.06 & 0.49 & 0.71 & 0.19 \\
\hline $\mathrm{NE}_{\mathrm{L}}$ maintenance, $\mathrm{Mcal} / \mathrm{d}$ & 9.48 & 9.12 & 9.25 & 9.33 & 0.13 & 0.93 & 0.27 & 0.08 \\
\hline $\mathrm{NE}_{\mathrm{L}}$ lactation, Mcal/d & 31.48 & 30.66 & 28.72 & 28.85 & 1.09 & 0.04 & 0.75 & 0.67 \\
\hline $\mathrm{NE}_{\mathrm{L}}$ balance, Mcal/d & 1.04 & -1.14 & 0.25 & -0.57 & 1.39 & 0.94 & 0.29 & 0.63 \\
\hline
\end{tabular}

${ }^{1}$ Enzyme mixture contained 1.93 and $0.40 \mathrm{~g} / \mathrm{kg}$ of TMR DM of Cellulase Plus and Xylanase Plus (Dyadic Inc., Jupiter, FL), respectively.

${ }^{2} \mathrm{M}=$ effect of maturity; $\mathrm{E}=$ effect of enzyme; $\mathrm{M} \times \mathrm{E}=$ interaction between maturity and enzyme. 
Table 5. Apparent digestibility of nutrients (\%) in lactating dairy cows fed diets based on 4 or 7 wk regrowth bermudagrass with or without fibrolytic enzymes ${ }^{1}$

\begin{tabular}{|c|c|c|c|c|c|c|c|c|}
\hline \multirow[b]{2}{*}{ Item } & \multicolumn{2}{|c|}{$4 \mathrm{wk}$} & \multicolumn{2}{|c|}{$7 \mathrm{wk}$} & \multirow[b]{2}{*}{ SEM } & \multicolumn{3}{|c|}{$P$-value ${ }^{2}$} \\
\hline & Control & Enzyme & Control & Enzyme & & M & $\mathrm{E}$ & $\mathrm{M} \times \mathrm{E}$ \\
\hline $\mathrm{NDF}$ & 57.4 & 55.6 & 50.2 & 51.0 & 1.27 & $<0.01$ & 0.71 & 0.31 \\
\hline $\mathrm{ADF}$ & 53.3 & 51.3 & 45.3 & 46.6 & 1.48 & $<0.01$ & 0.80 & 0.27 \\
\hline Diet $\mathrm{NE}_{\mathrm{L}},{ }^{3} \mathrm{Mcal} / \mathrm{kg}$ of $\mathrm{DM}$ & 1.84 & 1.81 & 1.72 & 1.75 & 0.02 & $<0.01$ & 0.83 & 0.19 \\
\hline
\end{tabular}

${ }^{1}$ Enzyme mixture contained 1.93 and $0.40 \mathrm{~g} / \mathrm{kg}$ of TMR DM of Cellulase Plus and Xylanase Plus (Dyadic Inc., Jupiter, FL), respectively.

${ }^{2} \mathrm{M}=$ effect of maturity; $\mathrm{E}=$ effect of enzyme; $\mathrm{M} \times \mathrm{E}=$ interaction between maturity and enzyme.

${ }^{3}$ Calculated from nutrient digestibility, according to NRC (2001) equations.

and ruminal microbial activity of cows fed the more digestible 4-wk diet as well as the greater ruminal fermentation as indicated by a lower ruminal $\mathrm{pH}$ (Table $6)$.

The greater total VFA concentration of cows fed the 4 -wk versus 7 -wk diet $(119$ vs. $108 \mathrm{mM} ; P<0.01)$ was mainly due to increased concentrations of acetate and propionate. This greater acid load coupled with the greater lactate concentration contributed to the lower ruminal $\mathrm{pH}$ of cows fed the 4 -wk versus 7 -wk diet $(6.09$ vs. $6.29 ; P<0.01)$. The 4 -wk diet may have modified the ruminal microbiota by decreasing the activity of lactate-utilizing microbes or increasing the activity of lactate-producing microbes, or both (Counotte and Prins, 1978). Nevertheless, NDF and ADF digestibilities of the 4-wk diet were high and the decrease in ruminal $\mathrm{pH}$ was not enough to impair ruminal digestion.

Valerate concentration was greater in cows fed the 4 -wk versus 7 -wk diet ( 1.28 vs. $1.03 \mathrm{mM} ; P<0.01)$. Ruminal valerate is mainly derived from 3 sources: pro- tein degradation (e.g., proline deamination (Dehority et al., 1958), carbohydrate degradation (Van Gylswyk, 1995), and VFA interconversion (Gray et al., 1952). In the current trial, VFA interconversion (condensation of acetate and propionate) appears to be the main reason why valerate concentration was greater in the 4-wk diet as it resulted in relatively greater concentrations of acetate and propionate.

Applying fibrolytic enzymes did not affect performance and ruminal fermentation of dairy cows. Contrary to our expectation, the fibrolytic enzymes did not improve apparent digestibility, feed intake, or milk yield of early-lactation cows. Supplementation of fibrolytic enzymes only increased milk lactose concentration by $1 \%$.

The exogenous fibrolytic enzyme responses in the current study agree with reviews that concluded that effects of fibrolytic enzymes on the performance of cattle are inconsistent (Beauchemin et al., 2003; Adesogan, 2005). Recently, Romero et al. (2016) reported

Table 6. Ruminal fermentation profile of lactating dairy cows fed diets based on 4 or 7 wk regrowth bermudagrass with or without fibrolytic enzymes $^{1}$

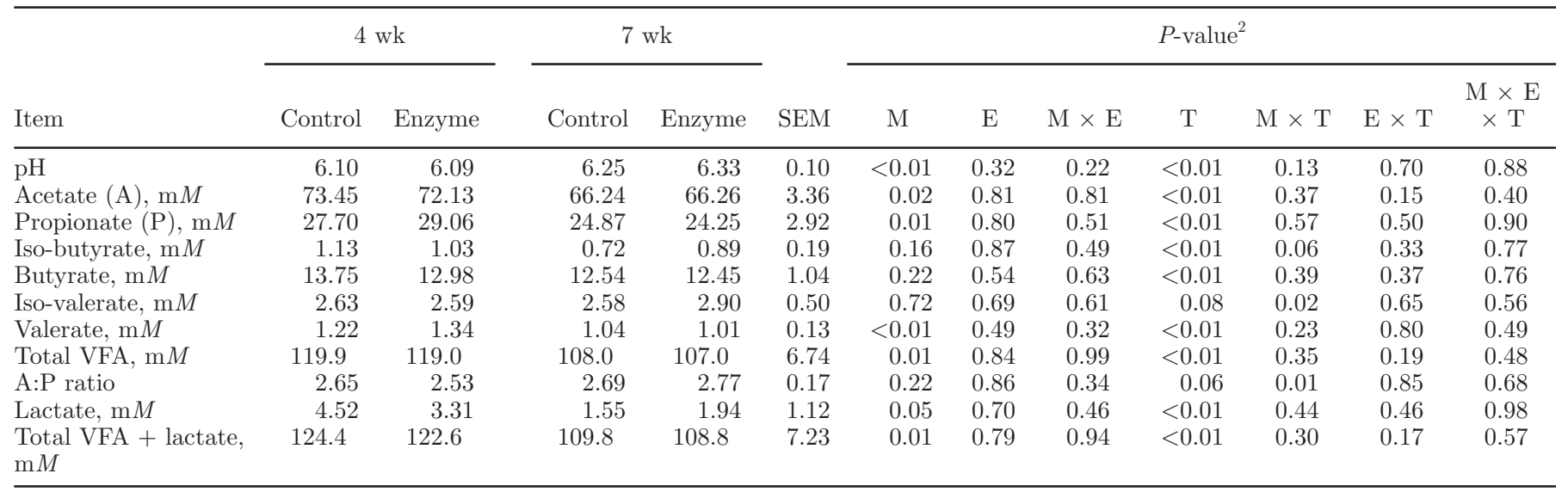

${ }^{1}$ Enzyme mixture contained 1.93 and $0.40 \mathrm{~g} / \mathrm{kg}$ of TMR DM of Cellulase Plus and Xylanase Plus (Dyadic Inc., Jupiter, FL), respectively. Samples were collected at $0,2,4,6,8$, and $10 \mathrm{~h}$ after the morning feeding.

${ }^{2} \mathrm{M}=$ effect of maturity; $\mathrm{E}=$ effect of enzyme; $\mathrm{M} \times \mathrm{E}=$ interaction between maturity and enzyme; $\mathrm{T}=$ effect of time after feeding; $\mathrm{M} \times \mathrm{T}=$ interaction between maturity and time; $\mathrm{E} \times \mathrm{T}=$ interaction between enzyme and time; $\mathrm{M} \times \mathrm{E} \times \mathrm{T}=$ interaction between maturity, enzyme and time. 
that addition of fibrolytic enzymes to a diet containing $10 \%$ of bermudagrass silage increased DMI and tended to increase FCM and milk fat yield, without affecting digestibility in early-lactation cows. In contrast, Bernard et al. (2010) and Dean et al. (2013) reported no effect of fibrolytic enzymes on DMI or performance of mid-lactation cows fed diets containing 12.5 and $35 \%$ of bermudagrass silage, respectively. This suggests that application of more potent exogenous fibrolytic enzymes at optimal doses or higher doses of many of the commercially available fibrolytic enzymes are needed to improve the performance of cows fed diets containing high proportions of bermudagrass.

Adesogan et al. (2014) discussed several plausible reasons for the variable efficacy of exogenous fibrolytic enzymes in animal trials. Because lignin has been recognized as the main impediment to the degradation of cell-wall polysaccharides (Hatfield et al., 2007), the inability of many of the existing exogenous enzymes to hydrolyze hydrocinnamic acid-lignin linkages in plant cell walls explains the poor or inconsistent response.

\section{CONCLUSIONS}

Feeding bermudagrass ensiled after 4 wk instead of 7 wk of regrowth improved energy intake and milk production of dairy cows in early lactation. Supplemental fibrolytic enzymes did not improve the performance of dairy cows fed diets containing $22.5 \%$ of bermudagrass silage (DM basis), regardless of forage maturity.

\section{ACKNOWLEDGMENTS}

The authors gratefully acknowledge funding for this project from Southeast Milk Incorporated, Belleview, Florida, and donation of the exogenous fibrolytic enzyme by Dyadic International, Jupiter, Florida. We also thank the staff of the University of Florida Dairy Unit for their assistance with the study.

\section{REFERENCES}

Adesogan, A. T. 2005. Improving forage quality and animal performance with fibrolytic enzymes. Pages 91-109 in Proc. Florida Ruminant Nutrition Symposium, Gainesville, FL. University of Florida-Institute of Food and Agricultural Sciences, Gainesville.

Adesogan, A. T., Z. X. Ma, J. J. Romero, and K. G. Arriola. 2014. Improving cell wall digestion and animal performance with fibrolytic enzymes. J. Anim. Sci. 92:1317-1330.

Akin, D. E., E. L. Robinson, F. E. Barton, and D. S. Himmelsbach. 1977. Changes with maturity in anatomy, histochemistry, chemistry, and tissue digestibility of bermudagrass plant parts. J. Agric. Food Chem. 25:179-186.

AOAC. 1990. Official Methods of Analysis. 15th ed. AOAC, Arlington, VA.

Arriola, K. G., S. C. Kim, and A. T. Adesogan. 2011. Effect of applying inoculants with heterolactic or homolactic and heterolactic bacteria on the fermentation and quality of corn silage. J. Dairy Sci. 94:1511-1516.

Bailey, M. J., P. Biely, and K. Poutanen. 1992. Interlaboratory testing of methods for assay of xylanase activity. J. Biotechnol. 23:257270 .

Beauchemin, K. A., D. Colombatto, D. P. Morgavi, and W. Z. Yang. 2003. Use of exogenous fibrolytic enzymes to improve feed utilization by ruminants. J. Anim. Sci. 81(E. Suppl. 2):E37-E47.

Bernard, J. K., J. J. Castro, N. A. Mullis, A. T. Adesogan, J. W. West, and G. Morantes. 2010. Effect of feeding alfalfa hay or Tifton 85 bermudagrass haylage with or without cellulase enzyme on performance of Holstein cows. J. Dairy Sci. 93:5280-5285.

Chambliss, C. G., R. L. Stanley Jr., and F. A. Johnson. 1999. Bermudagrass. Pages 23-28 in Florida Forage Handbook. C. G. Chambliss, ed. University of Florida Cooperative Extension Service, IFAS.

Counotte, G. H. M., and R. A. Prins. 1978. Regulation of rumen lactate metabolism and the role of lactic acid in nutritional disorders of ruminants. Vet. Sci. Commun. 2:277-303.

DairyOne. 2016. Interactive feed composition library. Accessed July 4, 2016. http://dairyone.com/analytical-services/feed-and-forage/ feed-composition-library/interactive-feed-composition-library/.

Dean, D. B., C. R. Staples, R. C. Littell, S. Kim, and A. T. Adesogan. 2013. Effect of method of adding a fibrolytic enzyme to dairy cow diets on feed intake digestibility, milk production, ruminal fermentation, and blood metabolites. Anim. Nutr. Feed Technol. 13:337-353.

Dehority, B. A., R. R. Johnson, O. G. Bentley, and A. L. Moxon. 1958. Studies on the metabolism of valine, proline, leucine and isoleucine by rumen microorganisms in vitro. Arch. Biochem. Biophys. 78:15-27.

Gray, F. V., A. F. Pilgrim, H. J. E. Rodda, and R. A. Weller. 1952. The nature and origin of the volatile fatty acids in the rumen of the sheep. J. Exp. Biol. 29:57-68.

Hatfield, R. D., H. J. G. Jung, G. Broderick, and T. C. Jenkins. 2007. Nutritional chemistry of forages. Pages 467-485 in Forages: The Science of Grassland Agriculture. R. F. Barnes, C. J. Nelson, K. J. Moore, and M. Collins, ed. Blackwell Publishing, Ames, IA.

Holt, E. C., and B. E. Conrad. 1986. Influence of harvest frequency and season on bermudagrass cultivar yield and forage quality Agron. J. 78:433-436.

Huhtanen, P. 1994. Forage influences on milk composition. Pages 144 162 in Proc. Nova Scotia Forage Conf.; Forage: Seeding to Feeding. The Nova Scotia Forage Council, Darthmouth, NS.

Jung, H., and M. S. Allen. 1995. Characteristics of plant cell walls affecting intake and digestibility of forages by ruminants. J. Anim. Sci. 73:2774-2790.

Kammes, K. L., and M. S. Allen. 2012. Nutrient demand interacts with grass maturity to affect milk fat concentration and digestion responses in dairy cows. J. Dairy Sci. 95:5133-5148.

Knowlton, K. F., J. M. McKinney, and C. Cobb. 2002. Effect of a direct-fed fibrolytic enzyme formulation on nutrient intake, partitioning, and excretion in early and late lactation Holstein cows. J. Dairy Sci. 85:3328-3335.

Kung, L., Jr., R. J. Treacher, G. A. Nauman, A. M. Smagala, K. M. Endres, and M. A. Cohen. 2000. The effect of treating forages with fibrolytic enzymes on its nutritive value and lactation performance of dairy cows. J. Dairy Sci. 83:115-122.

Lewis, G. E., W. K. Sanchez, C. W. Hunt, M. A. Guy, G. T. Pritchard, B. I. Swanson, and R. J. Treacher. 1999. Effect of direct-fed fibrolytic enzymes on the lactational performance of dairy cows. J. Dairy Sci. 82:611-617.

Lynch, J. P., L. Jin, J. S. Church, J. Baah, and K. A. Beauchemin. 2013. Fibrolytic enzymes and a ferulic acid esterase producing bacterial additive applied to alfalfa hay at baling: Effects on fibre digestibility, chemical composition and conservation characteristics. Grass Forage Sci. 70:85-93.

Mandebvu, P., J. W. West, R. N. Gates, and G. M. Hill. 1998. In vitro digestion kinetics of neutral detergent fiber extracted from Tifton 85 and Coastal bermudagrasses. Anim. Feed Sci. Technol. $73: 263-269$. 
Mandebvu, P., J. W. West, G. M. Hill, R. N. Gates, R. D. Hatfield, B. G. Mullinix, A. H. Parks, and A. B. Caudle. 1999. Comparison of Tifton 85 and Coastal bermudagrasses for yield, nutrient traits, intake, and digestion by growing beef steers. J. Anim. Sci. $77: 1572-1586$

NRC. 2001. Nutrient Requirements of Dairy Cattle. 7th rev. ed. National Academy Press, Washington, DC.

Oba, M., and M. S. Allen. 1999. Evaluation of the importance of the digestibility of neutral detergent fiber from forage: Effects on dry matter intake and milk yield of dairy cows. J. Dairy Sci. 82:589 596.

Romero, J. J., E. G. Macias, Z. X. Ma, R. M. Martins, C. R. Staples, K. A. Beauchemin, and A. T. Adesogan. 2016. Improving the performance of dairy cattle with a xylanase-rich exogenous enzyme preparation. J. Dairy Sci. In press.

Schingoethe, D. J., G. A. Stegeman, and R. J. Treacher. 1999. Response of lactating dairy cows to a cellulase and xylanase enzyme mixture applied to forages at the time of feeding. J. Dairy Sci. 82:996-1003.

Schneider, B. H., and W. P. Flatt. 1975. The indicator method. Page 168 in The Evaluation of Feeds Through Digestibility Experiments. Univ. Georgia Press, Athens.

Utley, P. R., R. S. Lowrey, W. H. Marchant, R. E. Hellwig, J. L. Butler, and W. C. McCormick. 1971. Comparative feeding value of pelleted Pensacola bahiagrass, Coastal bermudagrass and Coast- cross-1 bermudagrass harvested at four and eight weeks of age. J. Anim. Sci. 33:147-150.

Van Gylswyk, N. O. 1995. Factors limiting proliferation of desirable groups of bacteria in the rumen of animals fed poor quality feeds of high fibre content. Pages 121-129 in Rumen Ecology Research Planning. R. J. Wallace and A. Lahlou-Kassi, eds. The International Livestock Research Institute (ILRI). Addis Ababa, Ethiopia.

Van Soest, P. J., J. B. Robertson, and B. A. Lewis. 1991. Methods for dietary fiber, neutral detergent fiber, and nonstarch polysaccharides in relation to animal nutrition. J. Dairy Sci. 74:3583-3597.

Wildman, E. E., G. M. Jones, P. E. Wagner, R. L. Boman, H. F. Troutt Jr., and T. N. Lesch. 1982. A dairy cow body condition scoring system and its relationship to standard production characteristics. J. Dairy Sci. 65:495-501.

Wilson, J. R. 1993. Organization of forage plant tissues. Pages 1-32 in Forage Cell Wall Structure and Digestibility. H. G. Jung, D. R. Buxton, R. D. Hatfield, and J. Ralph, ed. ASA-CSSA-SSSA, Madison, WI, USA.

Wood, T. M., and M. K. Bhat. 1988. Methods for measuring cellulase activities. Pages 87-112 in Methods in Enzymology. Vol. 160. W. A. Wood, and S. T. Kellogg, ed. Academic Press Inc., London, UK.

Yang, W. Z., K. A. Beauchemin, and L. M. Rode. 2000. A comparison of methods of adding fibrolytic enzymes to lactating cow diets. J. Dairy Sci. 83:2512-2520. 